\title{
Diversity, knowledge, and valuation of plants used as fermentation starters for traditional glutinous rice wine by Dong communities in Southeast Guizhou, China
}

\author{
Jianwu He ${ }^{1,2,3}$, Ruifei Zhang ${ }^{1,2}$, Qiyi Lei ${ }^{4}$, Gongxi Chen ${ }^{3}$, Kegang Li ${ }^{3}$, Selena Ahmed ${ }^{5}$ and Chunlin Long ${ }^{1,2,6^{*}}$ (D)
}

\begin{abstract}
Background: Beverages prepared by fermenting plants have a long history of use for medicinal, social, and ritualistic purposes around the world. Socio-linguistic groups throughout China have traditionally used plants as fermentation starters (or koji) for brewing traditional rice wine. The objective of this study was to evaluate traditional knowledge, diversity, and values regarding plants used as starters for brewing glutinous rice wine in the Dong communities in the Guizhou Province of China, an area of rich biological and cultural diversity.
\end{abstract}

Methods: Semi-structured interviews were administered for collecting ethnobotanical data on plants used as starters for brewing glutinous rice wine in Dong communities. Field work was carried out in three communities in Guizhou Province from September 2017 to July 2018. A total of 217 informants were interviewed from the villages.

Results: A total of 60 plant species were identified to be used as starters for brewing glutinous rice wine, belonging to 58 genera in 36 families. Asteraceae and Rosaceae are the most represented botanical families for use as a fermentation starter for rice wine with 6 species respectively, followed by Lamiaceae (4 species); Asparagaceae, Menispermaceae, and Polygonaceae (3 species respectively); and Lardizabalaceae, Leguminosae, Moraceae, Poaceae, and Rubiaceae (2 species, respectively). The other botanical families were represented by one species each. The species used for fermentation starters consist of herbs (60.0\%), shrubs (23.3\%), climbers (10.0\%), and trees (6.7\%). The parts used include the root (21.7\%), leaf (20.0\%), and the whole plant (16.7\%). Findings indicate a significant relationship between knowledge of plants used as fermentation starters with age $(P$ value $<0.001)$ and educational status $(P$ value $=0.004)$ but not with gender $(P$ value $=0.179)$ and occupation $(P$ value $=0.059)$. The species that are most used by informants include Pueraria lobata var. montana (Lour.) van der Maesen (UV=1.74; Leguminosae), Actinidia eriantha Benth. (UV=1.51; Actinidiaceae), Oryza sativa L. var. glutinosa Matsum (UV=1.5; Poaceae).

Conclusion: This study highlights that while most of the Dong informants continue to use a diverse range of plants as a fermentation starter for brewing glutinous rice wine, knowledge of these plants is being lost by the younger generations. Documentation of traditional ethnobotanical knowledge and outreach is thus needed to conserve biocultural diversity in the rural Dong communities in southern China.

Keywords: Ethnobotany, Traditional ecological knowledge, Rice wine, Fermented beverage, Fermentation starters

\footnotetext{
* Correspondence: long@mail.kib.ac.cn; long.chunlin@muc.edu.cn

${ }^{1}$ College of Life and Environmental Sciences, Minzu University of China,

Beijing 100081, China

${ }^{2}$ Key Laboratory of Ethnomedicine (Minzu University of China), Ministry of

Education, Beijing 100081, China

Full list of author information is available at the end of the article
}

(c) The Author(s). 2019 Open Access This article is distributed under the terms of the Creative Commons Attribution 4.0 International License (http://creativecommons.org/licenses/by/4.0/), which permits unrestricted use, distribution, and reproduction in any medium, provided you give appropriate credit to the original author(s) and the source, provide a link to the Creative Commons license, and indicate if changes were made. The Creative Commons Public Domain Dedication waiver (http://creativecommons.org/publicdomain/zero/1.0/) applies to the data made available in this article, unless otherwise stated. 


\section{Background}

Fermented beverages have a long history of preparation and use globally for medicinal, social, and ritualistic purposes [1-4]. In China, different socio-linguistic groups in regions throughout the country have developed their own characteristic fermented beverages that are associated with cultural identity and social aspects of communities [3, 4]. For example, Guyuelongshan is a rice wine from Shaoxing in Zhejiang Province, Hejiu is a rice wine from Shanghai, and koumiss is a Mongolian liquor [5]. In addition, Tibetan communities prepare barley wine and there are many types of sweet rice wine from southwestern China including "nuomi" that are consumed during weddings, hospitality, funerals, ancestor worship, and other ceremonies [5].

Rice wine is among the most common and oldest fermented beverages in China. It is fermented using a fermentation starter, also known as koji (or jiuqu in Mandarin) [6]. Koji can be made with staple crops such as wheat, rice, millet, and maize that consist of microorganisms that support the fermentation process [7]. For example, communities in Shaoxing prepare koji as a raw material for rice wine from wheat that harbors many microorganisms including Absidia, Acetobacteria, Aspergillus, Bacillus, Mucor, Lactobacillus, and Rhizopus [8]. Some of these microorganisms are also used as single strains for the industrial manufacture of rice wine. Zhang et al. [9] highlighted that Aspergillus oryzae SU16, as a single strain, could be used in the production of koji.

In addition to common staple grains such as wheat, rice, millet, and maize for the preparation of fermentation starters, indigenous groups in mountainous regions of China have a long history of using a wide diversity of local plants for making koji. We previously documented a total of 103 species in 57 botanical families of wild plants that are traditionally used as starters for preparing fermented beverages by Shui communities in southwestern China [4]. The Dong are a socio-linguistic group (also known as the Kam) of southeast Guizhou that also have a long history of using koji for producing glutinous wine as a source of livelihood. Our previous studies demonstrate that the Dong people cultivate many varieties of glutinous rice $[10,11]$ which they use as their staple food. However, there remains a lack of documentation regarding the plants used as fermentation starters by Dong communities. This study seeks to address this knowledge gap by identifying the diversity of plants used as fermentation starters (koji) by Dong communities and associated knowledge and values. Findings have the potential to inform the conservation of natural resources associated with a culturally-relevant beverage of Dong communities while preserving traditional ecological knowledge.

\section{Methods}

\section{Study area}

Research was carried out in three Dong villages in Qiandongnan Miao and Dong Autonomous Prefecture in the southeastern part of Guizhou Province (longitude $108^{\circ} 50.3^{\prime} \mathrm{E}-109^{\circ} 58.5^{\prime} \mathrm{E}$, latitude $25^{\circ} 53.7^{\prime} \mathrm{N}-26^{\circ} 24.2^{\prime}$ $\mathrm{N})$, located near Hunan and Guangxi provinces. These villages are in the core zone of Dong socio-linguistic group and include Xiaohuang of Congjiang County, Huanggang of Liping County, and Nongwu of Rongjiang County (Fig. 1, Table 1). The three villages have a combined area of $51.22 \mathrm{~km}^{2}$ and are located between 630 and $780 \mathrm{~m}$ above sea level. The climate is characterized as subtropical monsoon humid with an annual average temperature of $18.4{ }^{\circ} \mathrm{C}$, an average precipitation of 1200 $\mathrm{mm}$, average sunlight time of $1300 \mathrm{~h}$, and a frost-free period of 310 days per year.

The three study site villages are dominated by members of the Dong and Miao socio-linguistic groups. Traditional rice-fish co-culture system predominates in these villages and integrates with animal husbandry, forestry management, and medicinal plant collection and trade $[10,11]$. In this study, we selected to focus on interviewing Dong households because of their longer history of cultivating glutinous rice (Oryza sativa var. glutinosa) compared to the Miao as well as their subsistence lifestyle for procuring food. Glutinous rice wine is a very popular fermented beverage in local communities. The Dong, as many indigenous communities, rely on their environment for a range of wild and cultivated crops for preparing food, beverages, and medicine [12, 13]. The above information indicates that these villages are ideal areas for studying the traditional knowledge of plants used as fermentation starters for traditional glutinous rice wine.

\section{Ethnobotanical data collection}

Ethnobotanical surveys were carried out from September 2017 to July 2018. A total of 217 informants (including 126 male and 91 female) were interviewed from the three study sites (Table 2). Semi-structured interviews were carried out using a snowballing approach of meeting Dong community members including in fields, around fish ponds, in canteens, in artisanal workshops, in farmhouses, and in village squares. The semi-structured interviews involved open-ended questions and conversations with informants in the above scenes. The major questions are as follows:

1. Do you know about "Jiuqu" (fermentation starters for brewing traditional glutinous rice wine)?

2. Do you know the technology of koji-making?

3. If yes, which plants did you choose, and which parts of the plants to make the fermentation starters? 

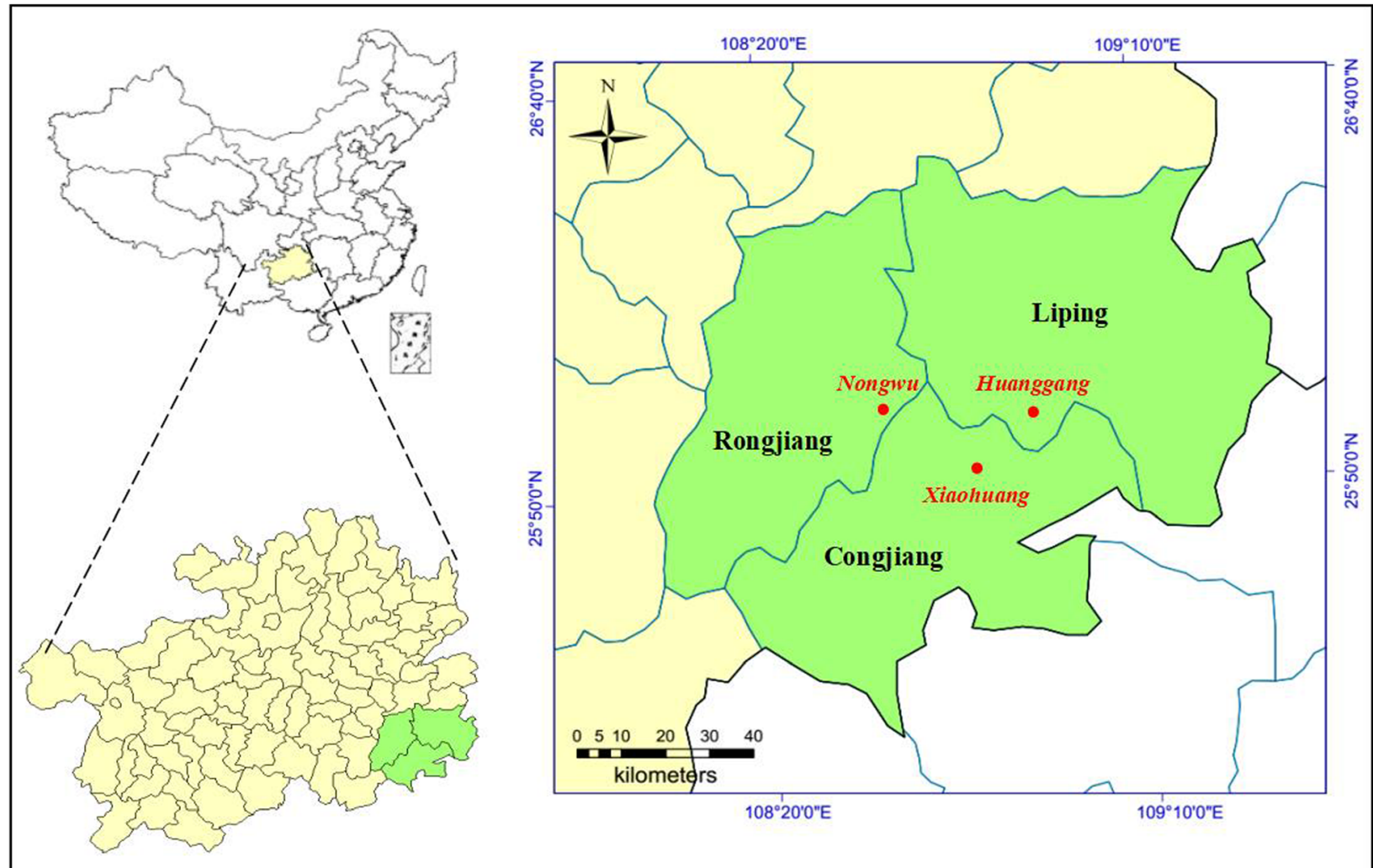

Fig. 1 Geographic location of the study area: Xiaohuang, Huanggang, and Nongwu in three counties of Congjiang, Liping, and Rongjiang, respectively (Qiandongnan Miao and Dong Autonomous Prefecture, China)

4. Where do you usually collect these plants?

5. Can you take us to collect these plants? (Field identification or local plant flora).

6. Do you know these plant names?

7. Can you read these names in Dong language?

8. Why do not you choose a commercial "Jiuqu" for brewing traditional glutinous rice wine?

9. Would you consider passing this knowledge to your children or other people?

10. What other interesting things can you share with us?

Interviews were carried out in either the Dong language with the assistance of a local Dong translator (Fig. 2) or in simplified Mandarin.

In the local area, people with primary and higher education tend to go out to work as migrant workers in non-agriculture times, and those with higher education have the opportunity to find permanent jobs in the provincial and prefectural capital cities, or county towns nearby. Interviews in Mandarin were primarily with individuals with primary education or above including migrant workers and local government officials. All interview procedures involved in this study were in accordance with the International Society of Ethnobiology Code of Ethics including procuring prior informed consent before interviews [14]. The demographic characteristics (age, educational status, and occupation) were identified and recorded in all face-to-face interviews (Fig. 2).

In addition to interviews, we carried out participatory observation in the study site communities. Specifically, we focused on observing the process of collecting plants and preparing koji. These observations were supplemented by key informant interviews on the type of plant species. All of the plants mentioned by key informants

Table 1 Study area (three Dong villages in Qiandongnan Miao and Dong Autonomous Prefecture)

\begin{tabular}{llllll}
\hline Village name & No. of family & Population & Area $\left(\mathrm{km}^{2}\right)$ & Altitude $(\mathrm{m})$ & Geographic location \\
\hline Xiaohuang (Congjiang) & 740 & 3800 & 16.53 & 630 & $25^{\circ} 53.7^{\prime} \mathrm{N}, 109^{\circ} 58.5^{\prime} \mathrm{E}$ \\
Huanggang (Liping) & 325 & 1629 & 29.70 & 780 & $26^{\circ} 24.2^{\prime} \mathrm{N}, 109^{\circ} 14.6^{\prime} \mathrm{E}$ \\
Nongwu (Rongjiang) & 135 & 550 & 4.99 & 740 & $25^{\circ} 94.1^{\prime} \mathrm{N}, 108^{\circ} 50.3^{\prime} \mathrm{E}$ \\
\hline
\end{tabular}


Table 2 Demographic details of interviewed informants

\begin{tabular}{llll}
\hline Category & Subcategory & $\begin{array}{l}\text { Number of } \\
\text { informants }\end{array}$ & $\begin{array}{l}\text { \% of } \\
\text { informants }\end{array}$ \\
\hline Gender & Male & 126 & 58.06 \\
Age & Female & 91 & 41.94 \\
& $20-40$ & 22 & 10.14 \\
& $40-60$ & 117 & 53.92 \\
Education status & Illiterate & 78 & 35.94 \\
& Primary & 152 & 70.05 \\
& Secondary & 16 & 20.28 \\
& Higher & 5 & 7.37 \\
Occupation & Farmer & 133 & 2.30 \\
& Migrant workers & 71 & 61.29 \\
& Local officials & 13 & 32.72 \\
Knowledge about & Yes & 193 & 5.99 \\
koji-making plants & No & 24 & 88.94 \\
\hline
\end{tabular}

were identified in the field and collected to prepare voucher specimens. We checked the scientific names of our field collections with The Plant List [15]. Botanical specimens were further examined at the Herbarium of Jishou University, Hunan Province, China. The specimens were assigned voucher numbers and deposited at the Herbarium of Jishou University.

\section{Data analysis}

Classical ethnobotanical descriptive statistics were used to summarize ethnobotanical data in Excel 2013. The association between indigenous knowledge of koji-making with participant's demographic factors including gender, age, educational status, and occupation was tested with Chi-square analysis. Statistical analysis was carried out using SPSS version 20 (SPSS, Chicago) at 5\% level of significance $(P<0.05)$. Use Value (UV) index [16] was calculated to evaluate the botanical species with the greatest use across the study site communities. The UV of each plant mentioned was calculated using the following formula:

$$
\mathrm{UV}=\frac{\sum \mathrm{UP}}{n}
$$

where UP is the number of uses mentioned by each informant for a given plant use and $n$ is the total number of informants.

\section{Results}

Socio-demographic characteristics of respondents

Table 2 describes the demographic characteristics of the 217 study informants. Informants comprised of 58.06\% $(N=126)$ males and $41.94 \%(N=91)$ females. In addition, informants were between the ages of 20 and 96 years (the

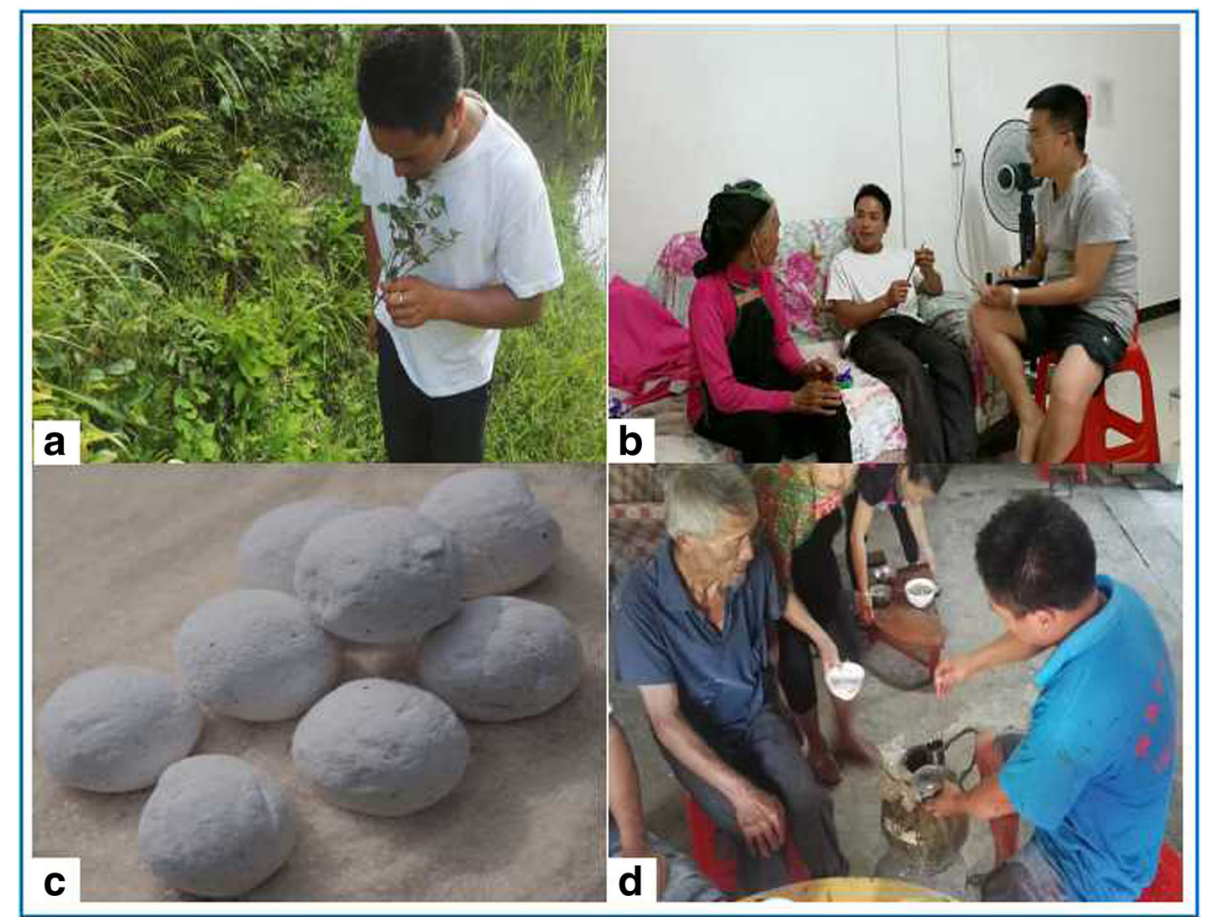

Fig. 2 Indigenous knowledge of traditional glutinous rice wine koji-making plants: a A local guide to helping identification of glutinous rice wine koji-making plants. b One of face-to-face interview. c The koji for brewing glutinous rice liquor/wine. $\mathbf{d}$ Glutinous rice wine made from koji 
majority were between 40 and 60 years old). Most of the surveyed respondents $(70.05 \%)$ are illiterate, and only five $(2.30 \%)$ of the interviewed respondents had completed higher education (Table 2). The majority of the respondents were farmers $(61.29 \%, N=133)$ and migrant workers $(32.72 \%, N=71)$, except for a few local government officials $(5.99 \%, N=13)$. Most respondents $(N=193$; 88.94\%) demonstrated average knowledge about koji plants in general (Tables 2 and 3).

\section{Diversity of plants used for koji}

A total of 60 plant species were documented for preparing koji, belonging to 58 genera and 36 families (Table 4). The most prevalent botanical families were Asteraceae and Rosaceae ( $N=6$, respectively), followed by Lamiaceae $(N=4)$; Asparagaceae, Menispermaceae, and Polygonaceae $(N=3$, respectively); Lardizabalaceae, Leguminosae, Moraceae, Poaceae, and Rubiaceae $(N=2$, respectively); and the other botanical families represented in our collections each consisted of a single species (Table 4).

Analysis of the life forms of koji-making plants showed that $60.0 \%$ of the reported species are herbaceous plants $(N=36), 23.3 \%$ are shrubs $(N=14), 10.0 \%$ are lianas $(10.0 \%)$, and $6.7 \%$ are trees $(N=4)$ (Table 4$)$. The root was the most commonly used plant part $(21.7 \%, N=13$ citations), followed by the leaf $(20.0 \%, N=12)$, whole plant $(16.7 \%, N=10)$, fruit $(13.3 \%, N=8)$, aerial part $(11.7 \%, N=7)$, branch $(10.0 \%, N=6)$, stem $(3.3 \%, N=2)$, bark, and flower (1.7\%, $N=1$, both) (Table 4, Fig. 3).
Traditional knowledge on koji-making plants

Results of the Chi-square test showed that there was no significant association between knowledge of the kojimaking plants and gender $\left(X^{2}=1.807, \mathrm{df}=1, P\right.$ value $=$ $0.179)$ and occupation $\left(X^{2}=5.664, \mathrm{df}=2, P\right.$ value $\left.=0.059\right)$. However, there was a significant association between knowledge of koji plants with age $\left(X^{2}=58.668, \mathrm{df}=2\right.$, $P$ value $<0.001)$ and educational status $\left(X^{2}=13.443, \mathrm{df}=3\right.$, $P$ value $=0.004)($ Table 3$)$. Informants older than 40 years and those with lower educational status were the most knowledgeable regarding plants for making koji (Table 3).

\section{Frequently utilized species}

The use values (UV) calculated for this study range from 0.27 to 1.74 , with a higher UV indicating the plant was more frequently reported to be used by informants. The plant species most frequently utilized by informants for making koji are Pueraria lobata var. montana (Lour.) van der Maesen (1.74), Actinidia eriantha Benth. (1.51), and Oryza sativa L. var. glutinosa Matsum (1.5). There were 23 other species with a UV value greater than 1 including Kadsura longipedunculata Finet et Gagnep, Houttuynia cordata Thunb., Mentha canadensis L., Rosa roxburghii Tratt, Polygonum pubescens (Meissn.) Steward, Rubus pluribracteatus L.T. Lu \& Boufford, Rosa laevigata Michx, Uncaria rhynchophylla (Miq.) Miq. ex Havil, Solanum americanum Mill., Cayratia trifolia (L.) Domin, Gaultheria leucocarpa Bl. var. crenulata (Kurz) T. Z. Hsu, Cunninghamia lanceolata (Lamb.) Hook, Frangula crenata (Siebold \& Zucc.) Miq., Gentiana

Table 3 Knowledge about koji-making plants in relation with gender, age, educational status, and occupation of the respondents

\begin{tabular}{|c|c|c|c|c|c|}
\hline \multirow[t]{2}{*}{ Characteristics } & \multirow{2}{*}{$\begin{array}{l}\text { Total number } \\
\text { of respondents }\end{array}$} & \multicolumn{2}{|c|}{ Knowledge about koji-making plants } & \multirow[t]{2}{*}{$x^{2}$} & \multirow[t]{2}{*}{$P$ value } \\
\hline & & Yes & No & & \\
\hline Gender & & & & $X^{2}=1.807, d f=1$ & $P=0.179$ \\
\hline Male & 126 & 109 & 17 & & \\
\hline Female & 91 & 84 & 7 & & \\
\hline Age & & & & $x^{2}=58.668, d f=2$ & $P<0.001$ \\
\hline $20-40$ & 22 & 9 & 13 & & \\
\hline $40-60$ & 117 & 108 & 9 & & \\
\hline 60 and older & 78 & 76 & 2 & & \\
\hline Education status & & & & $X^{2}=13.443, \mathrm{df}=3$ & $P=0.004$ \\
\hline None & 152 & 141 & 11 & & \\
\hline Primary & 44 & 38 & 6 & & \\
\hline Secondary & 16 & 11 & 5 & & \\
\hline Higher & 5 & 3 & 2 & & \\
\hline Occupation & & & & $X^{2}=5.664, d f=2$ & $P=0.059$ \\
\hline Farmers & 133 & 119 & 14 & & \\
\hline Migrant workers & 71 & 65 & 6 & & \\
\hline Local officials & 13 & 9 & 4 & & \\
\hline
\end{tabular}


Table 4 Inventory of plants traditionally used for koji-making in the study area (species are listed alphabetically)

\begin{tabular}{|c|c|c|c|c|c|c|c|}
\hline Scientific name & $\begin{array}{l}\text { Voucher } \\
\text { number }\end{array}$ & Family name & Dong name & Chinese name & Habit & Part used & UV \\
\hline Actinidia eriantha Benth. & KJBT0040 & Actinidiaceae & Sangp buc dongl & Mao Hua Mi Hou Tao & Shrub & Branch & 1.51 \\
\hline Adiantum flabellulatum L. & KJBT0052 & Pteridaceae & Kaok naeml & Shan Ye Tie Xian Jue & Herb & Leaf & 0.79 \\
\hline Agrimonia pilosa Ledeb & KJBT0029 & Rosaceae & Demh Meix Sais & Lu Bian Huang & Herb & Root & 0.47 \\
\hline Akebia quinata (Houtt.) Decne. & KJBT0064 & Lardizabalaceae & Gueel nyanl bads & Ba Yue Gua & Shrub & Fruit & 0.67 \\
\hline Arctium lappa $\mathrm{L}$. & KJBT0027 & Asteraceae & Mal kap gueec & Niu Bang & Herb & Aerial part & 0.45 \\
\hline Artemisia annua $\mathrm{L}$. & KJBT0019 & Asteraceae & Mal yaems sul & He Hao & Herb & Root & 1.19 \\
\hline Asarum forbesii Maxim. & KJBT0033 & Aristolochiaceae & Naos max tic & Ma Ti Xiang & Herb & Leaf & 0.77 \\
\hline $\begin{array}{l}\text { Asparagus cochinchinensis } \\
\text { (Lour.) Merr. }\end{array}$ & KJBT0050 & Asparagaceae & Sangp begs sangp laox & Tian Men Dong & Herb & Root & 0.56 \\
\hline $\begin{array}{l}\text { Bauhinia brachycarpa } \\
\text { Wall. ex Benth. }\end{array}$ & KJBT0059 & Leguminosae & Jaol bav & Ye Guan Men & Shrub & Root & 0.47 \\
\hline Cayratia trifolia (L.) Domin & KJBT0023 & Vitaceae & Jaol meixguv & San Ye Wu Lian Mei & Shrub & Fruit & 1.25 \\
\hline Cirsium japonicum DC. & KJBT0044 & Asteraceae & Mal sax bav laox & Da Ji & Herb & Root & 0.31 \\
\hline Clerodendrum cyrtophyllum Turcz. & KJBT0009 & Lamiaceae & Bav sup geel kuenp & Da Qing Ye & Shrub & Aerial part & 0.44 \\
\hline Codonopsis pilosula & KJBT0011 & Campanulaceae & Demh Gaams Yous & Dang Shen & Climber & Root & 0.40 \\
\hline $\begin{array}{l}\text { Cunninghamia lanceolata } \\
\text { (Lamb.) Hook. }\end{array}$ & KJBT0047 & Taxodiaceae & Meix beens & Sha Mu Ye & Tree & Leaf & 1.24 \\
\hline Cyclea racemosa Oliv. & KJBT0002 & Menispermaceae & Jaol enl sup dangl & Lun Huan Teng & Herb & Branch & 0.79 \\
\hline Diospyros cathayensis Steward & KJBT0048 & Ebenaceae & Meix bav minc & Shi Zi Ye & Tree & Leaf & 0.86 \\
\hline Elaeagnus pungens Thunb. & KJBT0051 & Elaeagnaceae & Demh nyox senc & Hu Tui Zi & Shrub & Aerial part & 0.78 \\
\hline Fallopia multiflora (Thunb.) Harald. & KJBT0018 & Polygonaceae & Jaol maenc yeex & He Shou Wu & Climber & Root & 0.28 \\
\hline Ficus pumila $\mathrm{L}$. & KJBT0006 & Moraceae & Jaol liangc fenx & Cheng Tuo Guo & Tree & Leaf & 0.27 \\
\hline Ficus tikoua Bur. & KJBT0013 & Moraceae & Jaol demh xeens & Di Gua Teng & Climber & Whole plant & 0.47 \\
\hline Gardenia jasminoides Ellis & KJBT0022 & Rubiaceae & Wap lagx ngoc & Huang Zhi Zi & Shrub & Flower & 1.03 \\
\hline $\begin{array}{l}\text { Gaultheria leucocarpa Bl. var. } \\
\text { crenulata (Kurz) T. Z. Hsu }\end{array}$ & KJBT0053 & Ericaceae & Melx demh miuus & Bai Zhu Shu & Herb & Leaf & 1.25 \\
\hline $\begin{array}{l}\text { Gentiana rhodantha Franch. } \\
\text { ex Hemsl. }\end{array}$ & KJBT0028 & Gentianaceae & Nyangt boy liongc & Long Dan Cao & Herb & Whole plant & 1.21 \\
\hline Gerbera piloselloides (L.) Cass. & KJBT0034 & Asteraceae & Sangp mal kap gav & Mao Da Ding Cao & Herb & Whole plant & 1.00 \\
\hline Geum macrophyllum Willd. & KJBT0030 & Rosaceae & Yangh muic naemx & Lu Bian Qing & Herb & Aerial part & 0.92 \\
\hline Glochidion puberum (Linn.) Hutch. & KJBT0049 & Phyllanthaceae & Meix sonp ponc & Suan Pan Zi & Tree & Fruit & 1.07 \\
\hline Gonostegia hirta (BI.) Miq. & KJBT0038 & Urticaceae & Mal kgoux lail & Nuo Mi Tuan & Herb & Whole plant & 0.92 \\
\hline $\begin{array}{l}\text { Hedera nepalensis var. sinensis } \\
\text { (Tobl.) Rehd. }\end{array}$ & KJBT0005 & Araliaceae & Jaol bav yaop & Chang Chun Teng & Shrub & Aerial part & 0.40 \\
\hline Houttuynia cordata Thunb. & KJBT0063 & Saururaceae & Sangp wadc & Zhe Er Gen & Herb & Root & 1.46 \\
\hline Imperata cylindrica (L.) Beauv. & KJBT0003 & Poaceae & Sangp nyangt bagx & Bai Mao Gen & Herb & Root & 1.12 \\
\hline $\begin{array}{l}\text { Kadsura longipedunculata } \\
\text { Finet et Gagnep. }\end{array}$ & KJBT0046 & Schisandraceae & Jaol dangl bogl padt & Shan Wu Wei Zi & Shrub & Bark & 1.47 \\
\hline Kalimeris indica (L.) Sch.-Bip. & KJBT0032 & Asteraceae & Mal langx & Ni Qiu Chuan & Herb & Aerial part & 0.76 \\
\hline Leonurus japonicus Houtt. & KJBT0060 & Lamiaceae & Mal semp beengc & Yi Mu Cao & Herb & Whole plant & 0.96 \\
\hline Ligularia fischeri (Ledeb.) Turcz. & KJBT0042 & Asteraceae & Bav dinl max & Ti Ye Tuo Wu & Herb & Branch & 0.46 \\
\hline Melastoma dodecandrum Lour. & KJBT0014 & Melastomataceae & Mal demh xeens & Di Shen & Shrub & Leaf & 0.79 \\
\hline Mentha canadensis & KJBT0043 & Lamiaceae & Naos suic yeex & $\mathrm{Bo} \mathrm{He}$ & Herb & Leaf & 1.46 \\
\hline Oryza sativa var. glutinosa Matsum. & KJBT0037 & Poaceae & Oux & Nuo He & Herb & Stem & 1.50 \\
\hline Paris polyphylla Smith & KJBT0039 & Melanthiaceae & Wap bar Yeal & Qi Ye Yi Zhi Hua & Herb & Whole plant & 0.55 \\
\hline Polygala sibirica $\mathrm{L}$. & KJBT0017 & Polygalaceae & Sangp jeml meec angh & Gua Zi Jin & Herb & Aerial part & 0.82 \\
\hline
\end{tabular}


Table 4 Inventory of plants traditionally used for koji-making in the study area (species are listed alphabetically) (Continued)

\begin{tabular}{|c|c|c|c|c|c|c|c|}
\hline Scientific name & $\begin{array}{l}\text { Voucher } \\
\text { number }\end{array}$ & Family name & Dong name & Chinese name & Habit & Part used & UV \\
\hline Polygonatum cyrtonema Hua & KJBT0021 & Asparagaceae & Xingp mant jenc & Huang Jing & Herb & Root & 1.00 \\
\hline Polygonum hydropiper L. & KJBT0026 & Polygonaceae & Meix bav & La Liao & Herb & Leaf & 1.42 \\
\hline Portulaca oleracea L. & KJBT0016 & Portulacaceae & Mal Nguedc & Gua Zi Cai & Herb & Whole plant & 1.00 \\
\hline $\begin{array}{l}\text { Pteridium aquilinum (L.) } \\
\text { Kuhn var. latiusculum (Desv.) } \\
\text { Underw. ex Heller }\end{array}$ & KJBT0062 & Dennstaedtiaceae & Kaok & Jue Cai & Herb & Stem & 0.92 \\
\hline $\begin{array}{l}\text { Pueraria lobata var. montana } \\
\text { (Lour.) van der Maesen }\end{array}$ & KJBT0015 & Leguminosae & Sangp nieengv & Ge Teng & Climber & Branch & 1.74 \\
\hline $\begin{array}{l}\text { Frangula crenata } \\
\text { (Siebold \& Zucc.) Miq. }\end{array}$ & KJBT0024 & Rhamnaceae & Meix liuucliic & Ku Li Ye & Shrub & Leaf & 1.22 \\
\hline Rohdea japonica (Thunb.) Roth & KJBT0054 & Asparagaceae & Mal nyinc sup & Wan Nian Qing & Herb & Root & 1.12 \\
\hline Rosa laevigata Michx & KJBT0065 & Rosaceae & Ongv kuaot & Jin Ying Zi & Shrub & Fruit & 1.38 \\
\hline Rosa roxburghii Tratt. & KJBT0007 & Rosaceae & Sunl ongv kuaot & Ci Li & Herb & Fruit & 1.44 \\
\hline $\begin{array}{l}\text { Rubus pluribracteatus } \\
\text { L.T.Lu \& Boufford. }\end{array}$ & KJBT0008 & Rosaceae & Demh bav daemh gal & Da Hei Mei & Climber & Fruit & 1.42 \\
\hline Sanguisorba officinalis L. & KJBT0020 & Rosaceae & Sangp lagx lugx yak & Hong Di Yu & Herb & Root & 0.81 \\
\hline $\begin{array}{l}\text { Sargentodoxa cuneata (Oliv.) } \\
\text { Rehd. et Wils. }\end{array}$ & KJBT0057 & Lardizabalaceae & Jaol bogl padt yak mags & Xue Teng & Herb & Branch & 1.20 \\
\hline Solanum americanum Mill. & KJBT0025 & Solanaceae & Lianh yeex & Ye Hai Jiao & Herb & Fruit & 1.29 \\
\hline Stephania cepharantha Hay. & KJBT0045 & Menispermaceae & Sunl maenc jinc & Jin Xian Diao Wu Gui & Herb & Root & 0.88 \\
\hline $\begin{array}{l}\text { Teucrium quadrifarium } \\
\text { Buch.-Ham. ex D. Don }\end{array}$ & KJBT0036 & Lamiaceae & Nyangt ous & Niu Wei Cao & Herb & Whole plant & 0.46 \\
\hline $\begin{array}{l}\text { Thalictrum microgynum } \\
\text { Lecoy. ex Oliv. }\end{array}$ & KJBT0056 & Ranunculaceae & Wangc lieenc naemx & Xiao Guo Tang Song Cao & Herb & Whole plant & 0.45 \\
\hline Tinospora sagittata Gagnep. & KJBT0004 & Menispermaceae & Sangp juc saengc & Qing Niu Dan & Shrub & Leaf & 0.47 \\
\hline $\begin{array}{l}\text { Uncaria rhynchophylla (Miq.) } \\
\text { Miq. ex Havil. }\end{array}$ & KJBT0010 & Rubiaceae & Sangp jaol kgoul daov & Da Ye Gou Teng Ye & Climber & Branch & 1.32 \\
\hline Verbena officinalis $\mathrm{L}$. & KJBT0031 & Verbenaceae & Nyangt piudt max bieenh & Ma Bian Cao & Herb & Leaf & 0.79 \\
\hline Viola philippica Cav. & KJBT0012 & Violaceae & Mal mac keip & Di Cao Guo & Herb & Whole plant & 0.47 \\
\hline Zanthoxylum bungeanum Maxim. & KJBT0066 & Rutaceae & Sangp siul yanl & Hua Jiao & Shrub & Fruit & 0.92 \\
\hline
\end{tabular}

rhodantha Franch. ex Hemsl, Sargentodoxa cuneata (Oliv.) Rehd. et Wils, Artemisia annua L., Imperata cylindrica (L.) Beauv, Rohdea japonica (Thunb.) Roth, Glochidion puberum (L.) Hutch, Gardenia jasminoides

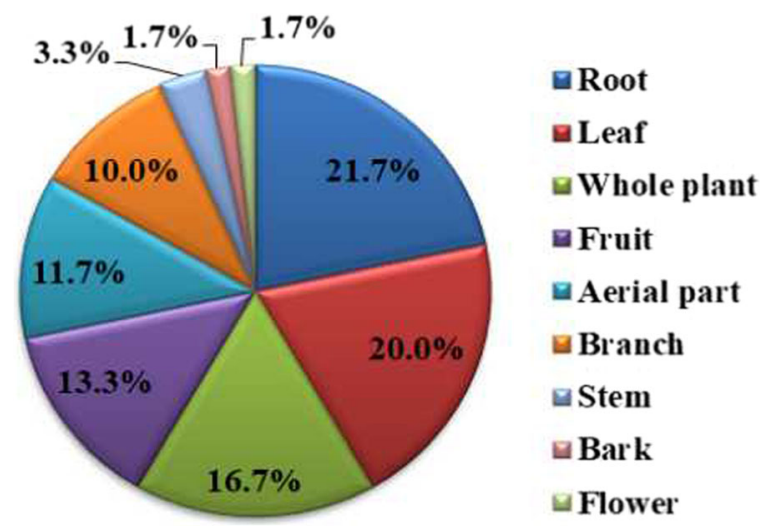

Fig. 3 Percentage of koji-making plant parts used
Ellis, Gerbera piloselloides (L.) Cass, Polygonatum cyrtonema Hua, and Portulaca oleracea (L.) (Table 4).

\section{Discussion}

The technique of using plants as fermentation starters is a prevalent traditional method for preparing many well-known fermented foods and beverages in China $[17,18]$. This study highlights the diversity of plants used by Dong communities as fermentation starters for making rice wine as well as associated knowledge and use value based on the most frequently reported plants used for koji. We documented a total of 60 plant species and associated plant parts used by informants in the Dong study site communities as fermentation starters for making glutinous rice wine. Our results further 
showed that $88.94 \%$ of respondents had knowledge about plants used as fermentation starters. This finding indicates the rich indigenous ecological knowledge regarding plants in Dong communities which contributes to sustaining livelihoods and well-being along with biodiversity.

Many informants claimed "People who cannot make glutinous rice wine are not a real Dong people, because drinking and singing become a part of our daily life." This naive view clearly emphasized the importance of fermented beverages in Dong communities and partially suggested that the koji for brewing glutinous rice wine was widely used in the area. Our results further showed that there was no significant difference in knowledge of $k o j i$ plants between gender or social occupation. These results suggest that koji plants are generally known by local people irrespective of their gender or job.

An older informant (the old woman in red shirt in Fig. 2b) said "Glutinous rice wine is easy to brew, but making koji is a profound knowledge that young people won't understand." This statement has been cross-validated among several other informants. Interestingly, the results of this survey showed a significant association between knowledge of koji plants and the respondent's age, indicating that elder people have more knowledge about koji plants than young people.

Although our results showed there was a significant negative correlation between the education level of respondents and the traditional knowledge on koji plants they possess, findings from this study are in line with another study that shows that educational status does not contribute to the mastery of traditional ecological knowledge [19]. But we cannot conclude that the education status decreased this traditional knowledge. Because the ratio of educated informants was too small, while education is more or less related to age (the younger people are more educated than older ones). It is worth mentioning that, in the study area, many young community members intend to go to distant cities for higher education from an early age. Thus, their communication with elders about traditional glutinous rice wine koji plants is limited.

The 60 species documented in this study represent a diverse range of botanical genera; specifically, the koji plants belong to 58 genera and 36 families with the dominant families including Asteraceae, Rosaceae, Lamiaceae, Asparagaceae, Menispermaceae, and Polygonaceae. A comparison of findings from this study with other regional surveys on plants used as fermentation highlights how species composition and diversity notably varies on the basis of cultural group. A survey by Hong et al. [4] with the Shui socio-linguistic group, also in Guizhou Province, documented that respondents harvested 103 wild plant species in 88 genera and 57 families used as starters for preparing fermented beverages. The majority of plants belonged to the families
Asteraceae, Rosaceae, Fabaceae, Melastomaceae, Moraceae, and Rutaceae. For example, Shui communities have been shown to use 9 species in the Rosaceae as fermentation starters (Agrimonia pilosa Ledeb., Geum aleppicum Jacq., Rosa roxburghii Tratt., Rosa laevigata Michx., Rubus alceaefolius Poir., Rubus corchorifolius L., Rubus ellipticus Sm., Rubus xanthocarpus Bureau \& Franch., and Rubus niveus Thunb.) while Dong communities use 6 species in the family for koji (Agrimonia pilosa Ledeb., Geum macrophyllum, Rosa laevigata Michx., Rosa roxburghii Tratt., Rubus pluribracteatus L., and Sanguisorba officinalis L.). This comparison demonstrates the distinctiveness in species composition among different socio-linguistic groups within the same region (Guizhou Province) of China. Through our interviews, we got a general understanding of traditional technology of local starter-making. They roughly mashed the cleaned plants and plant parts with a wooden hammer, then stirred the powder of the glutinous rice shell into the mixture until mixing, and then rubbed or rolled the mixture into a bolus between hands. After wetting the surface of the bolus with water from mountain springs, they put the mixture in a barrel and let it ferment naturally, and then place it in indoors for air drying after the surface of bolus has grown white mold.

At the same time, a comparison of findings from this study with other regional surveys on plants highlights how species composition and diversity may also show convergence between cultural groups. Specifically, the species composition found in this study has notable congruence to the general floristic profile of Miao community reported by Liu et al., which revealed that the Rosaceae, Asteraceae, Poaceae, and Liliaceae were dominant botanical families in Puding, Guizhou Province [20]. The analysis of the community structure of local plants in the study area confirms the rationality of the versatility hypothesis of Gaoue et al. [21]. The traditional practice of plant uses, along with the enhancement of the brewing technology, contributes to the diversity and complexity in the use of koji plants by the Dong.

As species and family level alone are not enough to comprehensively understand the keystone ethnobotanical species of koji plants, a quantitative evaluation method of calculating use values (UV) was applied in this study. UV is a commonly used indicator in the fields of ethnobotany and ethnoecology [15]. The evaluation of UV has the potential to reveal the utilization value of plant species and identify culturally-important plant resources [18]. Findings on UV in Dong communities showed that some parts of plant species had very restricted uses. For example, stems of Pueraria lobata var. montana, Actinidia eriantha, and glutinous rice were not reported in any published ethnobotanical studies as food or food raw materials. Alternatively, we found some 
koji plants widely reported in the literature as edible wild vegetables or fruits while having limited commercial use in the study area. Examples of these plants include Artemisia annua [22], Elaeagnus pungens [23], Houttuynia cordata [24], Portulaca oleracea [25], Pteridium aquilinum var. latiusculum (bracken fern) [26], Rosa laevigata, and Rosa roxburghii [27]. Additionally, we identified multiple other plants used by study informants for koji that have not been reported for this use in other geographical and sociocultural contexts, including "Naos suic yeex" (Mentha canadensis) and "Sangp siul yanl" (Zanthoxylum bungeanum). Mentha canadensis is a widely used plant to extract essential oil [28] and is also consumed in China for medicinal purposes in treating human diseases and to enhance appetite. The fruit of Zanthoxylum bungeanum is popular as a seasoning and traditional Chinese herbal medicine, and widely distributed in China and some Southeast Asian countries [29].

\section{Conclusion}

This study highlights that the majority of Dong informants in the study site communities continue to use a wide diversity of plants as fermentation starters for brewing glutinous rice wine, a tradition that is over a thousand years old. In addition, this study highlights that elders in study site communities continue to have richer traditional ecological knowledge regarding plants used as fermentation starters and that this knowledge is not being transmitted to the younger generation. The most prevalent koji plants reported in this study include Pueraria lobata var. montana (Lour.) van der Maesen stem, Actinidia eriantha Benth., and Oryza sativa var. glutinosa Matsum. stem. Findings of this study can be used to inform programs focused on the preservation of botanical resources used for preparing traditional glutinous rice wine edge. Similar to our findings of dye plants in the Dong area [30], we suggest supporting educational workshops and training focused on transmitting the traditional ecological knowledge of community elders to the younger generation. It is expected that such efforts will not only support the cultural identity of communities through the preservation of knowledge and practices, but will also help conserve surrounding biodiversity that is embedded in traditional ecological knowledge.

\section{Acknowledgements}

The authors acknowledge the local people in the study area. We also thank Professor Daoying Lan, Jishou University, China, for his critical reading and extensive comments on this manuscript.

\section{Funding}

This study was financed by the National Natural Science Foundation of China (31761143001, 31870316 \& 31560088), Key Laboratory of Ethnomedicine (Minzu University of China) of Ministry of Education of China (KLEM-ZZ201806), Minzu University of China (Collaborative Innovation Center for Ethnic Minority Development, YLDXXK201819), Ministry of Education of China and State Administration of Foreign Experts Affairs of China (B08044), the Special Funds
Project for Central Government Guides Local Science and Technology Development (2018CT5012), Open Programme of Center of Tujia Medical Research in Hunan Province, China (2017-6), and the Research Platform Foundation of Jishou University (JD201605, NLE201708).

\section{Availability of data and materials}

The data for this study may be availed upon request.

\section{Authors' contributions}

CLL conceived and designed the study. JWH and RFZ collected the data. QYL performed the statistical analysis. JWH, RFZ, GXC, KGL, and QYL participated in discussions. SA and CLL finalized the manuscript. All authors read and approved the final manuscript.

Ethics approval and consent to participate

We followed ethical guidelines adopted by the International Society of Ethnobiology (2008). Permissions were verbally informed by all participants in this study. All people appeared in Fig. 2 agreed to publish the photos.

\section{Consent for publication}

Not applicable

\section{Competing interests}

The authors declare that they have no competing interests.

\section{Publisher's Note}

Springer Nature remains neutral with regard to jurisdictional claims in published maps and institutional affiliations.

\section{Author details}

${ }^{1}$ College of Life and Environmental Sciences, Minzu University of China, Beijing 100081, China. ${ }^{2}$ Key Laboratory of Ethnomedicine (Minzu University of China), Ministry of Education, Beijing 100081, China. ${ }^{3}$ National and Local United Engineering Laboratory of Integrative Utilization Technology of Eucommia ulmoides, Jishou University, Jishou 416000, Hunan, China. ${ }^{4}$ School of Health Science, Kaili University, Kaili 556011, Guizhou, China. ${ }^{5}$ The Food and Health Lab, Department of Health and Human Development, Montana State University, Bozeman, MT 59717, USA. 'Kunming Institute of Botany, Chinese Academy of Sciences, Kunming 650201, China.

Received: 1 January 2019 Accepted: 5 April 2019

Published online: 27 April 2019

\section{References}

1. Sõukand R, Pieroni A, Biró M, Dénes A, Dogan $Y$, Hajdari A, Kalle R, Reade B, Mustafa B, Nedelcheva A, Quave CL, Łuczaj Ł. An ethnobotanical perspective on traditional fermented plant foods and beverages in eastern Europe. J Ethnopharmacol. 2015;170:284-96. https://doi.org/10.1016/j.jep. 2015.05.018.

2. Egea T, Signorini MA, Ongaro L, Rivera D, de Castro CO, Bruschi $P$. Traditional alcoholic beverages and their value in the local culture of the Alta Valle del Reno, a mountain borderland between Tuscany and EmiliaRomagna (Italy). J Ethnobiol Ethnomed. 2016;12:27. https://doi.org/10.1186/ s13002-016-0099-6.

3. McGovern PE, Zhang J, Tang J, Zhang ZQ, Hall RG, Moreau AR, et al. Fermented beverages of pre-and proto-historic China. Proc Natl Acad Sci U S A. 2004;101(51):17593-8. https://doi.org/10.1073/pnas.0407921102.

4. Hong LY, Zhuo JX, Lei QY, Zhou JJ, Ahmed S, Wang CY, et al. Ethnobotany of wild plants used for starting fermented beverages in shui communities of Southwest China. J Ethnobiol Ethnomed. 2015;11:42. https://doi.org/10. 1186/s13002-015-0028-0

5. Shen F, Wu J, Ying Y, Li B, Jiang T. Differentiation of Chinese rice wines from different wineries based on mineral elemental fingerprinting. Food Chem. 2013;141:4026-30. https://doi.org/10.1016/j.foodchem.2013.06.119.

6. Xu J, Wu H, Wang Z; Zheng F, Lu X, Li Z, et al. Microbial dynamics and metabolite changes in Chinese rice wine fermentation from sorghum with different tannin content. Sci Rep-UK. 2018;8(1):4639. https://doi.org/10.1038/ s41598-018-23013-1.

7. Teramoto Y, Okamoto K, Ueda S. Rice wine brewing with sprouting rice, sprouting rice infected with Aspergillus oryzae and rice koji. J Inst Brew. 2013;99:467-71. https://doi.org/10.1002/j.2050-0416.1993.tb01185.x. 
8. Hong X, Chen J, Liu L, Wu H, Tan H, Xie G, et al. Metagenomic sequencing reveals the relationship between microbiota composition and quality of Chinese rice wine. Sci Rep-UK. 2016;6:26621. https://doi.org/10.1038/srep26621.

9. Zhang B, Guan ZB, Cao Y, Xie GF, Lu J. Secretome of Aspergillus oryzae in Shaoxing rice wine koji. Int J Food Microbiol. 2012;155:113-9. https://doi. org/10.1016/j.ijfoodemicro.2012.01.014.

10. Lei Q, Zhou J, Zhang W, Luo J, Wu K, Long C. Morphological diversity of panicle traits in Kam fragrant glutinous rice ( Oryza sativa). Genet Resour Crop Evol. 2018;65:775-86. https://doi.org/10.1007/s10722-017-0570-9.

11. Lei Q, Zhou J, Luo J, Zhang W, Sun J, Long C. Changes in the numbers of Kam fragrant glutinous rice varieties in the Dong regions of Guizhou Province. Biodivers Sci. 2017;25:990-8. https://doi.org/10.17520/biods.2017119.

12. Ulijaszek SJ. Potential seasonal ecological challenge of heat strain among Australian aboriginal people practicing traditional subsistence methods: a computer simulation. Am J Phys Anthropol. 2001;116:236-45. https://doi. org/10.1002/ajpa.1119.

13. Haener MK, Dosman D, Adamowicz WL, Boxall PC. Can stated preference methods be used to value attributes of subsistence hunting by aboriginal peoples? A case study in Northern Saskatchewan. Am J Agr Econ. 2001;83: 1334-40. https://doi.org/10.1111/0002-9092.00287.

14. International Society of Ethnobiology 2006. International Society of Ethnobiology Code of Ethics (with 2008 additions). http://ethnobiology.net/ code-of-ethics/. Accessed 16 May 2017.

15. The Plant List. http://www.theplantlist.org. Accessed 10 Feb 2019.

16. Albuquerque UP, Lucena RFP, Monteiro JM, Florentino ATN. Evaluating two quantitative ethnobotanical techniques. Ethnobotany Res App. 2006;4:5160. https://doi.org/10.17348/era.4.0.51-60.

17. Chen $\mathrm{S}, \mathrm{Xu}$ Y. Effect of 'wheat Qu' on the fermentation processes and volatile flavour-active compounds of Chinese rice wine (Huangjiu). J I Brewing. 2013;119:71-7. https://doi.org/10.1002/jib.59.

18. Yan YZ, Qian YL, Ji FD, Chen JY, Han BZ. Microbial composition during Chinese soy sauce koji-making based on culture dependent and independent methods. Food Microbiol. 2013;34:189-95. https://doi.org/10. 1016/j.fm.2012.12.009.

19. Brosi BJ, Balick MJ, Wolkow R, Lee R, Kostka M, Raynor W, et al. Cultural erosion and biodiversity: canoe-making knowledge in Pohnpei, Micronesia. Conserv Biol. 2007;21:875-9. https://doi.org/10.1111/j.1523-1739.2007.00654.x.

20. Liu YG, Liu CC, Wei YF, Guo K. Species composition and community structure at different vegetation successional stages in Puding, Guizhou Province, China. Chin J Plan Ecolo. 2011;35:1009-18.

21. Gaoue OG, Coe MA, Bond M, Hart G, Seyler BC, Mcmillen H. Theories and major hypotheses in ethnobotany. Econ Bot. 2017:1-19. https://doi.org/10. 17520/biods.2017119.

22. de Magalhães PM, Dupont I, Hendrickx A, Joly A, Raas T, Dessy S, et al. Antiinflammatory effect and modulation of cytochrome P450 activities by Artemisia annua tea infusions in human intestinal Caco-2 cells. Food Chem. 2012;134:864-71. https://doi.org/10.1016/j.foodchem.2012.02.195.

23. Bijman J, Ruben R, Boekel MV, Tilburg AV, Trienekes J. The role of producer organisations in quality-oriented agrifood chains; an economic organisation perspective. New Phytol. 2007;72:493-6. https://doi.org/10.3920/978-908686-600-7.

24. Verma RS, Joshi N, Padalia RC, Singh VR, Goswami P, Kumar A, et al. Chemical composition and allelopathic, antibacterial, antifungal, and antiacetylcholinesterase activity of fish-mint (Houttuynia cordata Thunb.) from India. Chem Biodivers. 2017. https://doi.org/10.1002/cbdv.201700189.

25. Zhu H, Wang Y, Liu Y, Xia Y, Tang T. Analysis of flavonoids in Portulaca oleracea L. by UV-vis spectrophotometry with comparative study on different extraction technologies. Food Anal Method. 2010;3:90-7. https:// doi.org/10.1007/s12161-009-9091-2.

26. Tan L, Guo LZ, Song LM, Li DL, Liang W, Liu L. First report of Colletotrichum gloeosporioides causing leaf spot on Pteridium aquilinum in China. Plant Dis. 2017;101. https://doi.org/10.1094/pdis-12-16-1848-pdn.

27. Li X, Cao W, Shen Y, Li N, Dong XP, Wang KJ, et al. Antioxidant compounds from Rosa laevigata fruits. Food Chem. 2012;130:575-80. https://doi.org/10. 1016/j.foodchem.2011.07.076

28. Yu X, Liang C, Chen J, Qi X, Liu Y, Li W. The effects of salinity stress on morphological characteristics, mineral nutrient accumulation and essential oil yield and composition in Mentha canadensis L. Sci Hortic Amst. 2015;197: 579-83. https://doi.org/10.1016/j.scienta.2015.10.023.

29. Zhang Z, Liu J, Peng S, Cao Y, Lu X, Gao X, et al. Zanthoxylum bungeanum pericarp extract prevents dextran sulfate sodium-induced experimental colitis in mice via the regulation of TLR4 and TLR4-related signaling pathways. Int Immunopharmacol. 2016;41:127-35. https://doi.org/10.1016/j. intimp.2016.10.021.

30. Liu YJ, Ahmed S, Liu B, Guo ZY, Huang WJ, Wu XJ, Li SH, Zhou JJ, Lei QY, Long CL. Ethnobotany of dye plants in Dong communities of China. $J$ Ethnobiol Ethnomed. 2014;10:23. https://doi.org/10.1186/1746-4269-10-23.
Ready to submit your research? Choose BMC and benefit from:

- fast, convenient online submission

- thorough peer review by experienced researchers in your field

- rapid publication on acceptance

- support for research data, including large and complex data types

- gold Open Access which fosters wider collaboration and increased citations

- maximum visibility for your research: over $100 \mathrm{M}$ website views per year

At BMC, research is always in progress.

Learn more biomedcentral.com/submissions 